Економічні науки: збірник наукових праць Луцького національного технічного університету. Серія "Регіональна економіка". Випуск 18 (71). Редкол.: відп. ред. д.е.н., професор Л.Л. Ковальська. Луцьк: ІВВ Луцького НТУ, 2021. 278 с.

6.Власова Н.О., Чорна М.В., Бєляєва М.В. Економічний механізм регулювання підприємницької діяльності в роздрібній торгівлі: монографія. Харків: ХДУХТ, 2013. 155с.

7.Саблук О. Суть i принципи комерційного підприємництва i комерційної діяльності. Науковий вісник МНУ імені В.О. Сухомлинського. Економічні науки. 2018. № 1 (10).

\title{
References
}

1.Androsova T.V. (2001) Torhivlia v rynkovii ekonomitsi: navch. posibnyk. Kharkiv: KHDUKHT, 120 p. [In Ukrainian]

2.Vashchenko Yu.V. (2006) Bankivske pravo. Kyiv: Tsentr navchalnoi literatury. 344p. [In Ukrainian]

3.Vlasova N.O., Krasnousov A.V. (2005) Tepretychni aspekty zmistu "komertsiinoi diialnosti" pidpryiemsv torhivli. Ekonomika rozvytku. KHNEU. No. 2 (34). P. 66-68. [In Ukrainian]

4.Burak I.O. (2016) Kontseptualni pidchody do vyznachennia sutnosti ta vydiv torhovelnoi diialnosti. Molodyi vchenyi. No.3 (30). [In Ukrainian]

5.Vasilieva L.M. (2010) Poniattia i sutnist pidpryiemnytstva. Visnyk Dnipropetrovskoho derzhavnoho ahrarnoho universytetu. No.1. P.175-178. [In Ukrainian]

6.Vlasova N.O., Chorna M.V., Beliaieva M.B (2013) Ekonomichnyi mechanism reguliuvannia pidpryiemnytskoi dialnosti $\mathrm{v}$ rozdribnii torhivli: monohrafiia. Kharkiv: KHDUKHT, 155p. [In Ukrainian]

7.Sabluk O. (2018) Sut i pryntsypy komertsiinoho pidpryiemnytstva I komertsiinoi diialnosti. Naukovyi visnyk MNU imeni V.O.Sukhomlynskoho. Ekonomichni nauky. № 1 (10) [In Ukrainian]

DOI: $\underline{\text { htps://doi.org/10.36910/2707-6296-2021-18(71)-8 }}$

УДК 339.5:334.7

Корецька Н.І., к.е.н., доцент

Луцький національний технічний університет

\section{РОЛЬ ТРАНСНАЦІОНАЛЬНИХ КОРПОРАЦІЙ В ПРОЦЕСАХ ГЛОБАЛІЗАЦІЇ СВІТОВОЇ ЕКОНОМІКИ}

У статті досліджено роль транснаціональних компаній для міжнародного економічного розвитку, їх зосередження в регіонах світу. Розглянуто рейтинги найбільших транснаціональних корпорацій у світі у 2020 році. Визначено провідні 
Економічні науки: збірник наукових праць Луцького національного технічного університету. Серія "Регіональна економіка". Випуск 18 (71). Редкол.: відп. ред. д.е.н., професор Л.Л. Ковальська. Луиьк: ІВВ Луиького НТУ, 2021. 278 с.

ТНК за доходом та представлено їх поділ за країною базування та виробничою спеціалізацією.

Ключові слова: транснаціональні компанії, країни базування, виробнича спеціалізація.

\section{Koretska N.}

\section{THE ROLE OF TRANSNATIONAL CORPORATIONS IN THE PROCESSES OF GLOBALIZATION OF THE WORLD ECONOMY}

Transnational corporations are one of the most important and most dominant phenomena of the modern world economy, which make qualitatively new changes in the international economic space. The growth in the number of multinational companies and their activities is also reflected in changes in the sectoral structure and related changes in the geographical structure of TNCs.

Today, there are more than 70 thousands TNCs in the world and they control more than 860,000 branches worldwide. Increasingly, their total capital exceeds the total GDP of some countries, gaining a leading position in strategic types of international economy. Yes, they control more than $50 \%$ of world industrial production; $70 \%$ of international trade; $90 \%$ of foreign direct investment; more than $80 \%$ of patents and licenses for new equipment, technologies and know-how.

TNCs are the leading organizational structure in the international market and control a significant portion of international capital and trade. TNCs penetrate foreign markets, conquer them, achieve competitive advantages through corporate policy, support profits and profits, becoming leading players in the international market order with states.

The article analyzes the place of TNCs in international economic development, their concentration in the regions of the world.

Assessment of the geographical structure of the most powerful world TNCs prove the leadership of the United States among most countries, but with each year, their role decreases and China's influence grows.

A comparison of the annual income of TNCs with the GDP of some countries.

In 2020, the most common sector was technology, with large technologies dominating the top ten. A significant number of companies were characterized by the consumer, financial and medical sectors.

Thus, TNCs, controlling a significant part of the world's resources and using a significant share of the most qualified staff, occupy new market niches, seek to further expand economic power, provide additional opportunities for economic growth and economic development. Therefore, in view of the above, the problem of increasing the influence of TNCs and deepening the processes of transnationalization of the economy remains relevant.

Key words: multinational companies, home countries, production specialization. 
Економічні науки: збірник наукових праць Луцького національного технічного університету. Серія "Регіональна економіка". Випуск 18 (71). Редкол.: відп. ред. д.е.н., професор Л.Л. Ковальська. Луиьк: ІВВ Луиького НТУ, 2021. 278 с.

Корецкая Н.

\section{РОЛЬ ТРАНСНАЦИОНАЛЬНЫХ КОРПОРАЦИЙ В ПРОЦЕССАХ ГЛОБАЛИЗАЦИИ МИРОВОЙ ЭКОНОМИКИ}

В статье исследована роль транснациональных компаний для международного экономического развития, их сосредоточение в регионах мира. Рассмотрены рейтинги крупнейших транснациональных корпораций в мире в 2020 году. Определены ведущие ТНК по доходу и представлены их разделение по стране базирования и производственной специализации.

Ключевые слова: транснациональные компании, страны базирования, производственная специализация.

Постанова проблеми у загальному вигляді та її зв'язок 3 важливими науковими і практичними завданнями. В умовах інтеграційних, інтернаціоналізаційних і глобалізаційних процесів діяльність транснаціональних корпорацій є основною рушійною силою економічного зростання. 3 одного боку, глобалізація та регіоналізація створюють дуже хороші умови для розвитку транснаціональних корпорацій (ТНК), а з іншого - ТНК підсилюють ці процеси своїм експортом і здійсненням прямих іноземних інвестицій.

За визначенням Конференції ООН з торгівлі та розвитку (ЮНКТАД), транснаціональні корпорації - це підприємства, які складаються 3 материнського підприємства та його закордонних філіалів (при цьому ТНК можуть набувати як статусу корпорації, так і не мати його) [1].

До ТНК належать міжнародні компанії, показники діяльності яких задовольняють наступні критерії:

- наявність материнської компанії та підрозділів за кордоном не менше, ніж у 2 країнах світу (закордонні підрозділи можуть засновуватися компанією на основі прямих іноземних інвестицій шляхом створення виробничих потужностей або шляхом злиття та/або поглинання інших компаній;

- діяльність в різних правових, політичних і валютних системах;

- переважно централізований контроль і управління; 
Економічні науки: збірник наукових праць Луцького національного технічного університету. Серія "Регіональна економіка". Випуск 18 (71). Редкол.: відп. ред. д.е.н., професор Л.Л. Ковальська. Луиьк: ІВВ Луиького НТУ, 2021. 278 с.

- контроль активів підрозділів за кордоном (частка акціонерного капіталу в дочірній компанії, що належить материнській в іншій країні повинна становити від $10 \%$.

ТНК здійснюють діяльність в глобальному масштабі і нині, це компанії, фінансових капітал яких зосереджений в трьох найбільш розвинених регіонах світу: Північній Америці; Свропі; ПівденноСхідній Азії. I переважно це США, Великобританія, країни Свропейського Союзу, Японія, Китай, Індія.

Нині у світі нараховується більше 70 тис. ТНК і під їх контролем знаходиться більше 860 тис. філій по всьому світі. Все частіше їх загальний капітал перевищує загальне ВВП деяких країн, завойовуючи провідні позиції у стратегічних видах міжнародної економіки. Так, вони контролюють понад 50\% світового промислового виробництва; 70\% міжнародної торгівлі; $90 \%$ прямих іноземних інвестицій; понад 80\% патентів і ліцензій на нову техніку, технології та ноу-хау.

Аналіз останніх досліджень, у яких започатковано вирішення проблеми. Діяльності ТНК присвячено численні звіти ООН, СОТ, МВФ, конференції ООН 3 торгівлі та розвитку. Аналізу діяльності ТНК в регіонах світу присвячено дослідження вітчизняних (В. Белошапка, О. Білорус, В. Гарбар, Д. Лук'яненко, М. Лучко, Л. Руденко, В. Рокоч, О. Плотніков, інші) та зарубіжних вчених (П. Друкер, А. Мовсесян, А. Ругман, Б. Чуб, C. Шагурін, інші). Незважаючи на значний внесок цих та інших науковців, актуальність проблеми діяльності ТНК, на наш погляд, потребує подальшого дослідження.

Цілі статті: здійснення аналізу місця ТНК у міжнародному економічному розвитку, їх зосередження в регіонах світу.

Викладення основного матеріалу дослідження 3 повним обгрунтуванням отриманих наукових результатів. ТНК $\epsilon$ провідною організаційною структурою на міжнародному ринку і контролюють значну частину міжнародного капіталу та торгівлю. ТНК легко проникають на іноземні ринки, завойовуючи їх, досягають конкурентних переваг за допомогою проведеної корпоративної політики, отримують прибутки i надприбутки, 
Економічні науки: збірник наукових праць Луцького національного технічного університету. Серія "Регіональна економіка". Випуск 18 (71). Редкол.: відп. ред. д.е.н., професор Л.Л. Ковальська. Луцьк: ІВВ Луцького НТУ, 2021. 278 с.

стаючи головними гравцями на міжнародному ринку поряд 3 державами [2, с. 112].

Щороку журнал Forbes Global проводить дослідження щодо найбільших міжнародних компаній світу, в основі якого лежить такий критерій як виручка учасників.

Так, у 2018-2019 роках загальна виручка усіх ТНК рейтингу склала відповідно 32,7 та 33,3 трлн. дол., а прибуток - 2,15 та 2,1 трлн. дол. Сумарно в цих компаніях у ці роки працювало відповідно 69,3 і 69,9 млн. осіб. У квітні 2021 року стан 100 найбільших ТНК світу досяг рекордних 31,7 трлн. дол., що на $48 \%$ більше, ніж у 2020 році (при цьому варто зазначити, що у 2020 році сукупний ВВП США та Китаю склав 35,7 трлн дол.).

Щорічний рейтинг Forbes Global 2000 визначив найбільші публічні міжнародні компанії: 361 країни, представленої в рейтингу, найбільша кількість розташована в США (575 ТНК), Китаї та Гонконгу (309 ТНК), Японії (223 ТНК) (рис. 1).

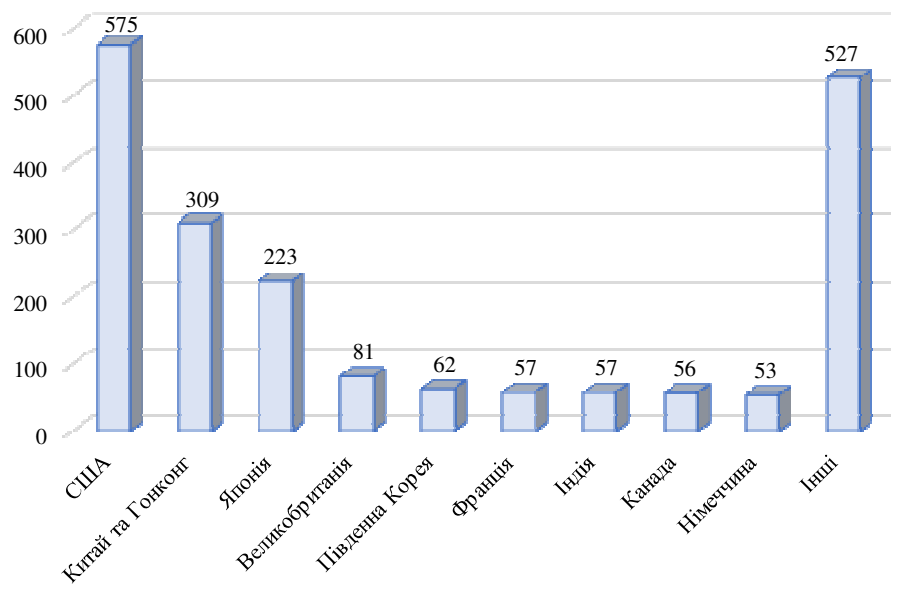

Рис. 1. Країни базування ТНК у 2020 році згідно з Forbes Global 2000

Примітка. Джерело: [3]

Отже, такі регіони світу як США, Китай і Гонконг, Японія є найбільш популярними місяцями розміщення штаб-квартир ТНК. 
Економічні науки: збірник наукових праць Луцького національного технічного університету. Серія "Регіональна економіка". Випуск 18 (71). Редкол.: відп. ред. д.е.н., професор Л.Л. Ковальська. Луцьк: ІВВ Луцького НТУ, 2021. 278 с.

Рейтинг 15 найбільших ТНК за Forbes Global 2000 подано в таблиці 1.

Таблиця 1

Рейтинг 15 найбільших ТНК за Forbes Global 2000

\begin{tabular}{|c|c|c|c|c|c|c|}
\hline Ранг & THK & Країна & $\begin{array}{c}\text { Продажі, } \\
\text { млрд. } \\
\text { дол. }\end{array}$ & $\begin{array}{l}\text { Прибуток, } \\
\text { млрд. дол. }\end{array}$ & $\begin{array}{c}\text { Активи, } \\
\text { млрд. } \\
\text { дол. }\end{array}$ & $\begin{array}{c}\text { Ринкова } \\
\text { вартість, } \\
\text { млрд. } \\
\text { дол. }\end{array}$ \\
\hline 1 & ICBC & Китай & 190,5 & 45,8 & 4914,7 & 249,5 \\
\hline 2 & $\begin{array}{l}\text { JPMorgan } \\
\text { Chase }\end{array}$ & США & 136,2 & 40,4 & 3689,3 & 464,8 \\
\hline 3 & $\begin{array}{l}\text { Berkshire } \\
\text { Hathaway }\end{array}$ & США & 245,5 & 42,5 & 873,7 & 624,4 \\
\hline 4 & $\begin{array}{l}\text { China } \\
\text { Construction } \\
\text { Bank } \\
\end{array}$ & Китай & 173,5 & 39,3 & 4301,7 & 210,4 \\
\hline 5 & $\begin{array}{l}\text { Saudi Arabian } \\
\text { Oil Company } \\
\text { (Saudi } \\
\text { Aramco) }\end{array}$ & $\begin{array}{c}\text { Саудівська } \\
\text { Аравія }\end{array}$ & 229,7 & 49,3 & 510,3 & 1897,2 \\
\hline 6 & Apple & США & 294 & 63,9 & 354,1 & 2252,3 \\
\hline 7 & $\begin{array}{ll}\text { Bank } & \text { of } \\
\text { America } & \\
\end{array}$ & США & 98,8 & 17,9 & 2832,2 & 336,3 \\
\hline 8 & $\begin{array}{l}\text { Ping An } \\
\text { Insurance } \\
\text { Group } \\
\end{array}$ & Китай & 169,1 & 20,8 & 1453,8 & 211,2 \\
\hline 9 & $\begin{array}{l}\text { Agricultural } \\
\text { Bank of } \\
\text { China }\end{array}$ & Китай & 153,9 & 31,3 & 4159,9 & 140,1 \\
\hline 10 & Amazon & США & 386,1 & 21,3 & 321,2 & 1711,8 \\
\hline 11 & $\begin{array}{l}\text { Samsung } \\
\text { Electronics }\end{array}$ & $\begin{array}{c}\text { Південна } \\
\text { Корея }\end{array}$ & 200,7 & 22,1 & 348,2 & 510,5 \\
\hline 12 & Toyota Motor & Японія & 249,4 & 14,3 & 561,9 & 219,2 \\
\hline 13 & Alphabet & США & 182,4 & 40,3 & 319,6 & 1538,9 \\
\hline 14 & $\begin{array}{l}\text { Bank of } \\
\text { China }\end{array}$ & Китай & 134 & 27,9 & 3731,4 & 116,7 \\
\hline 15 & Microsoft & США & 153,3 & 51,3 & 304,1 & 1966,6 \\
\hline
\end{tabular}

Примітка. Джерело: [3]

Недивлячись на торгову напруженість з Китаєм, фінансові звіти ТНК, нове американське податкове законодавство тощо, 
Економічні науки: збірник наукових праць Луцького національного технічного університету. Серія "Регіональна економіка". Випуск 18 (71). Редкол.: відп. ред. д.е.н., професор Л.Л. Ковальська. Луцьк: ІВВ Луцького НТУ, 2021. 278 с.

першу позицію займав промислово-комерційний банк Китаю (7-й рік поспіль), який контролював активи на суму понад \$4,9 трлн.

В цілому згідно $з$ даними рейтингу 15 ТНК, Китай в 2020 році твердо займав п'ять лідируючих позицій (ICBC, China Construction Bank, Ping An Insurance Group, Agricultural Bank of China, Bank of China. Причиною зростання ролі ТНК в Китаї є досягнення нею найвищих темпів економічного розвитку, отримання найкращих результатів у міжнародній торгівлі, визнання іï як головного торгового партнера.

Також до рейтингу Forbes Global 2000 входили сім ТНК США: JP Morgan Chase, Berkshire Hathaway, Apple, Bank of America, Amazon, Alphabet, Microsoft. Така ситуація свідчить про потужний економічний потенціал цих обох країн.

Найбільші ТНК за виробничою спеціалізацією розподілені на рисунку 2.

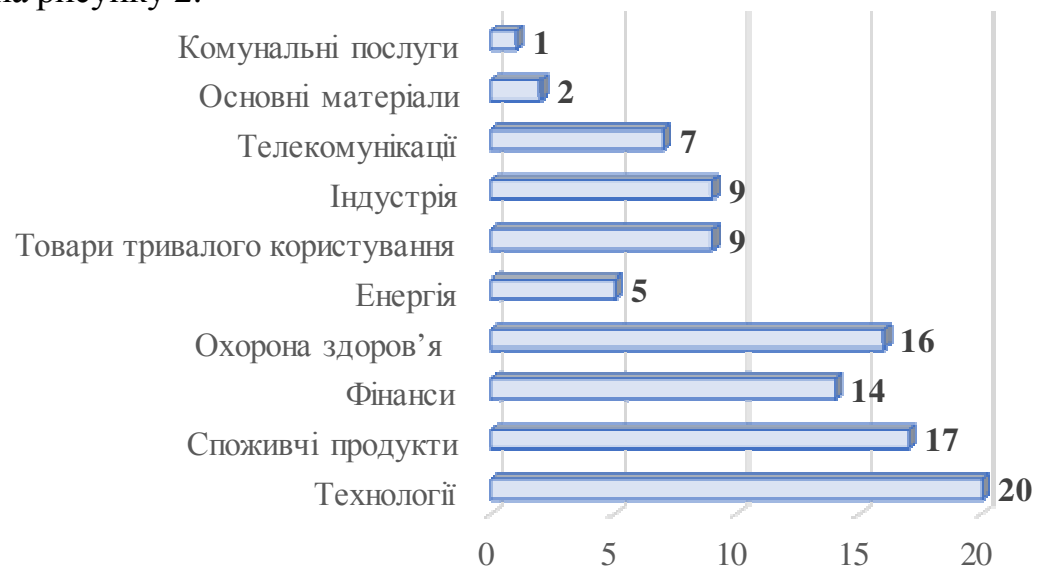

Рис. 2. Поділ 100 найбільших ТНК за виробничою спеціалізацією у 2020 році, \%

Примітка. Джерело: [3]

3 даних рисунку 2 видно, що у 2020 році найбільш поширеним сектором був технологічний, при цьому великі технології домінували в першій десятці. Значною кількістю компаній характеризувалися споживчий, фінансовий та медичний сектори. 
Економічні науки: збірник наукових праць Луцького національного технічного університету. Серія "Регіональна економіка". Випуск 18 (71). Редкол.: відп. ред. д.е.н., професор Л.Л. Ковальська. Луцьк: ІВВ Луцького НТУ, 2021. 278 с.

Порівняємо доходи ТНК (див. табл. 1) і ВВП країн їх базування (табл. 2).

Таблиця 2

Порівняння доходів найбільших транснаціональних корпорацій світу з ВВП країн базування (2020 р.)

\begin{tabular}{|c|c|c|c|}
\hline Країна & $\begin{array}{c}\text { ВВП, } \\
\text { млрд. } \\
\text { дол. }\end{array}$ & ТНК & $\begin{array}{c}\text { Доходи, } \\
\text { млрд. дол. }\end{array}$ \\
\hline \multirow{5}{*}{ Китай } & \multirow{5}{*}{24191} & ICBC & 190,5 \\
\hline & & China Construction Bank & 173,5 \\
\hline & & Ping An Insurance Group & 169,1 \\
\hline & & Agricultural Bank of China & 153,9 \\
\hline & & Bank of China & 134,0 \\
\hline \multirow{7}{*}{ США } & \multirow{7}{*}{20894} & JPMorgan Chase & 136,2 \\
\hline & & Berkshire Hathaway & 245,5 \\
\hline & & Apple & 294 \\
\hline & & Bank of America & 98,8 \\
\hline & & Amazon & 386,1 \\
\hline & & Alphabet & 182,4 \\
\hline & & Microsoft & 153,3 \\
\hline $\begin{array}{l}\text { Саудівська } \\
\text { Аравія }\end{array}$ & 1869,3 & $\begin{array}{l}\text { Saudi Arabian Oil Company (Saudi } \\
\text { Aramco) }\end{array}$ & 229,7 \\
\hline Південна Корея & 2307,7 & Samsung Electronics & 200,7 \\
\hline Японія & 5451,5 & Toyota Motor & 249,4 \\
\hline
\end{tabular}

Взявши до уваги лише перші ТНК-лідери за кожною країною, можна зробити висновок, що частка доходу усіх ТНК у порівнянні з ВВП країни базування, буде значною.

Висновки. Отже, ТНК, контролюючи значну частину світових ресурсів і використовуючи значну частку найбільш кваліфікованого персоналу, займають нові ринкові ніші, прагнуть до подальшого розширення економічної влади, дають додаткові можливості для економічного зростання і розвитку економіки країн світу. Тому 3 огляду на вище наведене проблема збільшення впливу ТНК і поглиблення процесів транснаціоналізації економіки залишається актуальною.

Географічна структура найпотужніших світових ТНК засвідчує лідерство США серед більшості країн, проте з кожним роком зростає вплив Китаю як країни базування. Галузями, в 
Економічні науки: збірник наукових праць Луцького національного технічного університету. Серія "Регіональна економіка". Випуск 18 (71). Редкол.: відп. ред. д.е.н., професор Л.Л. Ковальська. Луцьк: ІВВ Луцького НТУ, 2021. 278 с.

яких ТНК найбільш розвиваються і показують найбільший приріст прибутку, $є$ технологічне виробництво, споживчий сектор, фінанси та охорона здоров'я.

В цілому, роль ТНК у світовій економіці постійно зростає. Їх сильні позиції обумовлені функціями, які вони виконують [4]:

- рух ресурсів, потужність виробництва і торгівлі;

- стимулювання розвитку та економічної ефективності;

- реструктуризація;

- посилення ринкової конкуренції;

- інтеграція корпорацій та економік.

Тому активізація діяльності ТНК відкриває нові можливості для економіки кожної країни, сприяє інтеграції та підвищенню конкурентоспроможності на міжнародному ринку.

\section{Список бібліографічного опису}

1.World Investment Report 2007: Transnational Corporations, Extractive Industries and Development. UNCTAD, United Nations. New York and Geneva, 2007.

2.Волошко Н.О. Транснаціональні корпорації: теоретико-методологічні основи організації діяльності в умовах глобалізації економіки. Економіка та держава №7. 2020. С. 110-113.

3. GLOBAL 2000. How The World's Biggest Public Companies Endured The Pandemic. URL: https://www.forbes.com/lists/global2000/\#36685b455ac0

4.Monika Wyrzykowska, Ph.D. Torun School of Banking Role of transnational corporations in the international trade. URL: https://www.etsg.org/ETSG2010/papers/Wyrzykowska.pdf

\section{References}

1. Vorld Ynvestment Report 2007: Transnatyonal Tsorporatyons, Ekhtratstyve Yndustryes and Development. NNTsTAD, Nnyted Natyons. Nev blork and Heneva, 2007.

2. Voloshko N. O. Transnacionalni korporacii: teoretiko-metodologichni osnovi organizacii diyalnosti v umovah globalizacii ekonomiki. Ekonomyka ta derzhava №7. 2020. S. $110-113$.

3. HLOBAL 2000. Khov Tkhe Vorlds Byhhest Publyts Tsompanyes Endured Tkhe Pandemyts. NRL: khttps://vvv.forbes.tsom/lysts/hlobal2000/\#36685b455ats0

4. Monyka Vurzukovska, Pkh.D. Torun Shchool of Bankynh Role of transnatyonal tsorporatyons yn tkhe ynternatyonal trade. NRL: https://vvv.etsh.orh/ETSH2010/papers/Vыrzыkovska.pdf

DOI: https://doi.org/10.36910/2707-6296-2021-18(71)-9 